\author{
ks. Stanisław Dyk ${ }^{1}$ \\ 0000-0001-7337-0035
}

Katolicki Uniwersytet Lubelski Jana Pawła II

\title{
Działanie Ducha Świętego w Eucharystii a przepowiadanie homilijne
}

Kościół żyje i wzrasta tam, gdzie działa Duch Święty. Uprzywilejowaną, bo sakramentalną, a przez to także i obiektywną przestrzenią obecności i działania Ducha Świętego jest celebracja liturgiczna. W to sakramentalne działanie Ducha Świętego włączona jest homilia. W celebracji Duch Święty tak ubogaca kościelne przepowiadanie, że staje się ono słowem Bożym - a tym samym nośnikiem Bożego zbawienia. Dzięki tchnieniu Ducha homilia dociera do uczestników gromadzenia liturgicznego jako słowo święte, zbawiające. Duch działa także na słuchacza, by mógł on słowo Boże usłyszeć, przejąć i przyjąć ${ }^{2}$. W poniższym opracowaniu jednak przepowiadanie homilijne ukazane będzie nie tyle jako przestrzeń

\footnotetext{
1 Ks. prof. dr hab. Stanisław Dyk - kapłan diecezji kieleckiej; wykładowca homiletyki i teologii ewangelizacji na Katolickim Uniwersytecie Lubelskim Jana Pawła II w Lublinie; wiceprzewodniczący Stowarzyszenia Homiletów Polskich; kierownik Katedry Homiletyki KUL; redaktor naczelny „Przeglądu Homiletycznego”; redaktor 12 zeszytu „Roczników Teologicznych KUL” - Homiletyka; konsultor w Komisji Duszpasterstwa Konferencji Episkopatu Polski; autor książek oraz kilkudziesięciu artykułów naukowych; ostatnie publikacje zwarte: Nowa ewangelizacja - konkretne wezwanie (Gubin 2015); Homilia - droga do żywego poznania misterium Chrystusa (Kielce 2016). E-mail: standyk@kul.pl.

2 Por. S. Dyk, Duch Święty jako podmiot i treść przepowiadania homilijnego, „Studia Pastoralne" 4 (2008) nr 4, s. 148-159.
} 
działania Ducha Świętego, ile od strony swej materialnej zawartości. Zostanie przedstawiona podstawowa treść tego przepowiadania, związana z działaniem Ducha Świętego w Eucharystii.

Przypomnijmy w tym miejscu, że homilia jest integralną częścią celebracji liturgicznej i ma te same funkcje, co ona. Mówiąc inaczej: homilia pozostaje $\mathrm{w}$ funkcji liturgii. Tym samym homilia powinna być niejako ukierunkowana na wprowadzenie wiernych w zbawcze działanie Boga w liturgii, które urzeczywistnia się w Duchu Świętym. Wyraźnie określił to już pięćdziesiąt lat temu Heribert Mühlen w swoim artykule pt. Die Wirksamkeit des Heilligen Geistes als Ermöglichung jeglichen liturgischen Tuns ${ }^{3}$, co (za Stanisławem Czerwikiem) można przetłumaczyć jako: „Działanie Ducha Świętego jako umożliwienie wszelkiej czynności liturgicznej”. Celem artykułu będzie zatem odpowiedź na pytania: Jakie jest podstawowe działanie Ducha Świętego w liturgii eucharystycznej? Jaka powinna być treść homilii, aby oddać specyfikę tego działania? Jak wprowadzać wiernych w liturgiczne misterium Ducha Świętego?

\section{Chrystologiczne ukierunkowanie katechezy pneumahagijnej}

Najpierw należy przypomnieć, że każda Eucharystia jest Pięćdziesiątnicą - jest wylaniem Ducha Świętego. Trzeba pamiętać, że liturgia dokonywana jest w Duchu Świętym we wszystkich swoich wymiarach. Mamy tu zatem obecność Ducha Świętego w zgromadzeniu liturgicznym, w osobie przewodniczącego, w liturgii słowa, w modlitwie Kościoła, w liturgii sakramentalnej ${ }^{4}$. Warto tu jednak wskazać na moment epiklezy konsekracyjnej, która jest uobecnieniem Paschy Pana. A Pascha to przecież

3 H. Mühlen, Die Wirksamkeit des Heilligen Geistes als Ermöglichung jeglichen liturgischen Tuns. Zum Verständnis der Aussagen der „Constitutio de sacra liturgia” über die Präsenz Christi, „Liturgie in der Gemeinde” 2 (1995), s. 40-61.

4 Każda celebracja liturgiczna, czy to rozumiana integralnie, czy też w jakiejkolwiek swojej części jest epifanią Ducha Świętego. Zob. S. Czerwik, Obecność i działanie Ducha Świętego we wspólnocie świeckich i duchownych sprawujących liturgię, „Przegląd Pastoralno-Homiletyczny" 2 (1998) nr 2, s. 60-86; A. M. Triacca, La celebrazione liturgica, epifania dello Spirito Santo, „Liturgia” 33 (1999), s. 24-46. 
także Pięćdziesiątnica: „Wielkanoc jest Pięćdziesiątnicą. Wielkanoc jest już darem Ducha Świętego" 5 . Każda Eucharystia jest zatem uobecnieniem Pięćdziesiątnicy. To wydarzenie jest jasno wyrażone w epiklezie konsekracyjnej, „w której kapłan prosi Ojca o posłanie Ducha Uświęciciela, by składane ofiary stały się Ciałem i Krwią Chrystusa i aby wierni, przyjmując je, sami stawali się ofiarą dla Boga" (KKK 1105). Zatem modlitwa ta, jak też i cała Eucharystia każdorazowo może wyzwalać w uczestnikach zgromadzenia liturgicznego doświadczenie „życia w Duchu”.

W tym miejscu należy postawić pytanie: Na czym polega owo liturgiczne „życie w Duchu Świętym”? Otóż pragnieniem i dziełem Ducha Świętego jest, aby uczestnicy zgromadzenia liturgicznego żyli życiem Chrystusa zmartwychwstałego (por. Konstytucja o liturgii świętej [dalej: KL], 1091). W uczestnikach zgromadzenia liturgicznego przy pomocy Ducha Świętego ma się dokonać to, co dokonało się w Chrystusié. Można powiedzieć zatem śmiało, że właśnie takiemu celowi podporządkowane jest szczególne dzieło Ducha w celebracji eucharystycznej. Nie dziwi to wcale albowiem każda celebracja liturgiczna jest zorientowana chrystocentrycznie: dotyczy Chrystusa i jest sprawowana przez Chrystusa - Najwyższego Kapłana. Stąd też i homilijna katecheza o Duchu Świętym winna być ujęta w kluczu chrystologicznym. Homilia jest wszakże przepowiadaniem misterium Chrystusa (por. KL 35,2; OWMR 65) ${ }^{7}$. Tym samym homilia daje doskonałą okazję ku temu, aby przestrzegać ważnej zasady teologicznej, mówiącej, że pneumatologię można przedstawiać w sposób poprawny jedynie w ścisłym związku z chrystologią - jak sformułował to Benedykt XVI - „Ducha dostrzega się nie w odejściu od Syna, lecz w wejściu w Niego".

W przepowiadaniu homilijnym warto pamiętać o tym, że podobnie jak w całej historii zbawienia, tak też i w celebracji, która jest historią

Kongregacja Kultu Bożego i Dyscypliny Sakramentów, Dyrektorium homiletyczne, tłum. P. Borkowski, Poznań 2015 [dalej: DH], nr 56.

6 W. Świerzawski, Duch Święty wobec misterium Chrystusa w sprawowaniu liturgii, w: Fundamentalne rzeczywistości liturgii, red. W. Świerzawski, Sandomierz 2012, s. 142.

7 Por. DH, nr 12-15.

8 J. Ratzinger/Benedykt XVI, Bóg Jezusa Chrystusa. Medytacje o Bogu Trójjedynym, Kraków 2006, s. 107. 
zbawienia in actu (por. KL 2) zachodzi zasada ścisłej koleracji pomiędzy misją Syna i Ducha. Działanie jednej z tych Osób Boskich przywołuje automatycznie działanie drugiej. Tak, jak Chrystus i Jego misterium stanowi centrum historii zbawienia, tak Duch Święty jest główną siłą sprawczą w dopełnieniu tego misterium: Chrystus dokonuje, Duch dopełnia ${ }^{9}$. Stąd też Ducha Świętego nazywa się „,współdziałającym z Chrystusem”, , przyłączającym się do Chrystusa", duszą obecności Chrystusa ${ }^{10}$. Katechizm tą jedność działania Chrystusa i Ducha w sakramentach opisuje w sposób następujący: „Sakramenty będące «mocami, które wychodzą» z zawsze żywego i ożywiającego Ciała Chrystusa oraz działaniami Ducha Świętego urzeczywistnianymi w Jego Ciele, którym jest Kościół, są «arcydziełami Bożymi» w nowym i wiecznym Przymierzu" (KKK 1116).

W homilii należy zatem ukazać wiernym, jak w liturgii Duch Święty działa razem z Chrystusem, aby nas wprowadzać w proces odkupienia, aby odkupienie dokonane przez Chrystusa „czynić żywym i skutecznym w duszy każdego człowieka"11; jak w liturgii Duch Święty prowadzi Kościół do doskonałej jedności ze swoim Oblubieńcem gdy razem ze zgromadzeniem liturgicznym woła do Chrystusa: „Przyjdź Panie Jezu” (Ap 22,17) ${ }^{12}$.

Działanie Ducha Świętego ukierunkowane na Chrystusa polega w Eucharystii przede wszystkim na przygotowaniu wiernych na przyjęcie Chrystusa, uobecnianiu misterium Chrystusa oraz aktualizowaniu tego misterium w życiu ludu Bożego. Dynamikę takiego działania Ducha w celebracji eucharystycznej precyzyjnie oddają trzy modlitwy: kolekta, modlitwa eucharystyczna i modlitwa po Komunii Świętej. Kolekta - która jest

9 „Duch Święty sprawia, że Chrystus, który odszedł, przychodzi - teraz i zawsze w nowy sposób. To nowe przychodzenie Chrystusa za sprawą Ducha Świętego i Jego stała obecność i działanie w życiu duchowym dokonują się w rzeczywistości sakramentalnej”. Jana Paweł II, Encyklika „Dominum et Vivificantem” o Duchu Świętym w życiu Kościoła i świata, w: Encykliki Ojca Świętego Jana Pawła II, Kraków 1996, nr 61.

10 B. Migut, Teologia liturgiczna szkoły rzymskiej, Lublin 2007, s. 240; Por. A. M. Triacca, L ' „Hodie” liturgico tra tempo ed eternità: contributo per una visuale cristiana del tempo, „Ephemerides Liturgicae" 116 (2002), s. 377.

${ }^{11}$ Jan Paweł II, List apostolski „Tertio Millennio adveniente” do biskupów, duchowieństwa i wiernych w zwiazku z przygotowaniem Jubileuszu Roku 2000, Poznań 1995, nr 44.

12 Por. W. Świerzawski, Duch Święty wobec misterium Chrystusa w sprawowaniu liturgii, dz. cyt., s. 138-140. 
nie tylko modlitwą zbierającą obrzędy wstępu, lecz także wprowadzającą do lektury słowa Bożego - ukazuje działanie Ducha, który odsłania przed wiernymi misterium Chrystusa ukryte w tekstach świętych. Duch przypomina misterium Chrystusa, gdy „udziela czytającym i słuchającym duchowego zrozumienia słowa Bożego" i łaski wiary (por. KKK 1101-1102). Duch Święty przychodzi wówczas do uczestników jako żywa pamięć tradycji Kościoła (por. J 14,26), aby sugerować, nauczać i świadczyć o misterium Chrystusa (por. J 14, 26; 15, 26; 16, 7). W ten sposób Duch jawi się jako pierwszy Egzegeta słowa Bożego ${ }^{13}$ (por. KKK 1099). Dodajmy przy tym, że Duch Święty przychodzi wraz z proklamowanym słowem Bożym nie tylko po to, by pomóc je zrozumieć, przyjąć i nim żyć, lecz także po to, aby siebie w tym słowie udzielić ${ }^{14}$.

Modlitwa eucharystyczna z kolei jest momentem, w którym Duch Święty pod postaciami chleba i wina aktualizuje i uobecnia misterium paschalne Chrystusa, a w nim całe Jego zbawcze dzieło. Duch Święty aktualizuje zatem misterium zbawienia i uświęcenia, które dokonało się raz jeden w historii i pomaga w ten sposób wejść w życie Boga Trójjedynego. Duch Święty, który „wszystkim ofiarowuje możliwość dojścia w sposób Bogu wiadomy do uczestnictwa w te paschalnej tajemnicy" (KDK 22) ${ }^{15}$ jawi się w celebracji jako najważniejszy Mistagog.

Modlitwa po Komunii Świętej z kolei wyraża działanie Ducha Uświęciciela, który przemienia wierzących na podobieństwo Chrystusa i sprawia, że także poza celebracją eucharystyczną uczestniczą oni w posłaniu Chrystusa, zabiegają o jedność Kościoła oraz dają świadectwo chrześcijańskiej miłości (por. KKK 1105-1109) ${ }^{16}$.Poprzez takie uświęcające działanie Duch Święty pomaga wierzącym złączyć swą wolę z wolą Boga

13 Por. A. M. Triacca, La celebrazione liturgica, epifania dello Spirito Santo, s. 31; A. M. Triacca, Omelia e Spirito Santo: sua presenza ed azione e come parlarne, „Liturgia” 32 (1998), s. 145-148.

14 Według S. Marsiliego to w Słowie Bóg przekazuje swego Ducha. Słowo, które pozostaje zawsze natchnione, tzn. stworzone przez Ducha, jest także zawsze nosicielem Ducha, tzn. inspiruje do dania odpowiedzi Bogu w czasie kultu. S. Marsili, Mistero di Cristo e liturgia nello Spirito, Città del Vaticano 1986, s. 174.

15 Sobór Watykański II, Konstytucja duszpasterska o Kościele w świecie współczesnym „Gaudium et spes", w: Konstytucje. Dekrety. Deklaracje, Poznań 2002, s. 554.

16 M. Sodi, Teologia liturgiczna sztuka syntezy teologicznej, w: Teologia liturgiczna. W poszukiwaniu syntezy w teologii, red. B. Migut, Lublin 2013, s. 131. 
i wybierać „to, co zawsze wybierał Jego Syn” (KKK 2825). W ten sposób Duch przyczynia się do nieustannego pogłębienia życia duchowego chrześcijan poprzez wzrost ich przemiany na wzór Chrystusa ${ }^{17}$. Należy zatem często przypominać wiernym, że Bóg Ojciec może ukształtować w nich obraz swego Syna tylko przez Ducha Świętego. Człowiek może być w swym życiu nosicielem Chrystusa (cristoforo) tylko wtedy, gdy jest nosicielem Ducha (pneumatoforo) ${ }^{18}$.

Wspomniane trzy ważne modlitwy eucharystyczne ukazujące dynamikę działania Ducha Świętego w Eucharystii wskazują ważną specyfikę homilii pneumahagijnej. Otóż powinna być ona zorientowana zarówno kerygmatycznie, jak też mistagogicznie i egzystencjalnie. Innymi słowy, w homilii chodzi o katechezę ukazującą działanie Ducha Świętego, który odsłania misterium Chrystusa w słowie Bożym, uobecnia je w celebracji liturgicznej oraz odtwarza to misterium w życiu wierzących. Ważnym celem homilii jest sprawić, aby wierni zaś będą mogli świadomie sprawować Eucharystię właśnie w „Duchu Świętym”. Dzieje się tak, kiedy stają się oni dojrzałymi uczestnikami misterium Chrystusa, a zwłaszcza Jego Paschy. W ten sposób Lud Boży jest formowany przez „obiektywny kształt” Chrystusa i przez „życie wewnętrzne” Ducha Świętego. Ów kształt dostrzegamy patrząc na Chrystusa, a realizujemy poprzez obecność i działanie w nas Ducha ${ }^{19}$. Dzięki takiej eucharystycznej formacji - jak to stwierdza Wacław Świerzawski - „Kościół staje się naocznym świadkiem obecności Pana, liturgia epifanią, a nasz życie poza świątynią staje się apokalipsą: objawia eschatologiczny wymiar obyczajów, etos świata mającego nadejśćc"20.

17 B. Migut, Teologia liturgiczna szkoły rzymskiej, dz. cyt., s. 237.

18 Por. A. M. Triacca, Spiritualità, w: Dizionario di omiletica (DO), a cura di M. Sodi, A. M. Triacca, Torino-Bergamo 1998, s. 1509n.

19 G. Greshake, Być kapłanem dzisiaj, Poznań 2005, s. 174n.

20 W. Świerzawski, Duch Święty wobec misterium Chrystusa w sprawowaniu liturgii, dz. cyt., s. 138 . 


\section{Homilia wprowadzeniem w doświadczenie Ducha Świętego}

Biorąc pod uwagę historiozbawcze znaczenie liturgii, a tym samym fakt, że również i homilia jako część liturgii jest momentem historii zbawienia in actu trzeba stwierdzić, że przepowiadanie homilijne winno posiadać podwójną charakterystykę. Z jednej strony ma polegać na przekazie integralnej katechezy o Duchu Świętym, z drugiej zaś ma prowadzić do każdorazowego przyjęcia owego daru Ducha w Eucharystii, swoistego odnowienia się w Duchu Świętym. Z jednej strony chodzi o przekaz tego, jak Duch Święty w ciągu roku liturgicznego stopniowo objawia Boga, bogactwo Jego wewnętrznego życia, Jego zbawcze dzieło ${ }^{21}$. Z drugiej strony o ukazanie Go jako aktywnego podmiotu zbawczego działania.

Tym samym przepowiadanie homilijne może być antidotum wobec niektórych, współczesnych uproszczeń w nauce o Duchu Świętym. Uproszczenia te znajdują wyraz albo w nazbyt doktrynalnym ujęciu prawdy o Duchu Świętym albo w nadmiernym łączeniu tej nauki $\mathrm{z}$ antropologią przez podkreślanie głownie tego, co Duch Święty czyni w człowieku22.

W pierwszym przypadku zapomina się o tym, że w homilii należy prowadzić do poznania misterium Boga nie w sposób li tylko teoretyczny, pojęciowy, ale do „poznania głębszego” (św. Paweł nazwie je: epignosis), czyli do wewnętrznego doświadczenia Boga w Duchu Świętym. Wacław Świerzawski odnośnie homilii powie, że nie można w niej prowadzić do poznania misterium „w sensie ludzkiego rozumowania, poznawania tajemnic tylko w warstwie racjonalnej bez dotknięcia miłości objawiającego się Boga”. Takie poznawanie było by „raczej początkiem pychy języka" 23. Pismo Święte zostało przecież spisane z perspektywy

21 Liturgia jest wszakże syntezą historii zbawienia i spełnia rolę Objawienia. Por. S. Marsili, La liturgia, momento stolico della salvezza, w: La liturgia, momento storico della salvezza, a cura di S. Marsili, Torino 1974, s. 92 (Anàmnesis, 1). Liturgia jest także wyjaśnieniem słowa Bożego, choć zawsze ukierunkowanym na zbawcze misterium i życie człowieka.

22 W. Chrostowski, Biblijna nauka o Duchu Świętym, w: Jesteśmy napełnieni Duchem Świętym: zeszyt teologiczno-pastoralny, red. J. Bartoszek, R. Chromy, K. Piechaczek, Katowice 2017, s. 45 (Program duszpasterski Kościoła w Polsce na Rok 2017-2018, 4).

${ }_{23}$ W. Świerzawski, Kaznodzieja jako mistagog, w: Sługa Słowa, red. W. Przyczyna, Kraków 1997, s. 112n. 
doświadczenia zbawczych interwencji Boga. Zbawienie dokonuje się zatem w historii oraz w relacji osobowej - zbawienie zawsze się dzieje i to dzieje się pomiędzy osobami. Nie jest czymś statycznym, lecz dynamicznym - jest przeżywane. Taki bowiem (dynamiczny) jest sam Bóg. Boga i Jego spraw powinno się zatem przedstawiać nie tyle za pomocą jakiegoś teoretycznego opisu, co raczej jako Boga działającego. W liturgii przekaz teologii należy zawsze kierunkować w stronę praktycznego wymiaru chrześcijańskiej egzystencji ${ }^{24}$. Najlepiej pomożemy wiernym poznać Ducha Świętego, gdy włączymy ich w Jego zbawcze działanie.

W drugim przypadku - gdy podkreśla się głównie działanie Ducha Świętego w człowieku - może dojść do koncentracji na subiektywnych odczuciach, pobożnych emocjach, czy jakichś spektakularnych doznaniach. Wówczas w centrum stawia się nie Ducha Świętego, lecz człowieka. Celem takiego kontaktu z Duchem Świętym może być głównie to, co psychologia nazywa „przeżyciem” wskazując na jego silny związek z podmiotem poznającym i na obecność momentu emocjonalno-uczuciowego, który może pozbawić zdolności realnego myślenia ${ }^{25}$. W takim podejściu może dochodzić też do fragmentarycznego ujęcia biblijnej nauki o Duchu Świętym, jakby jedynym darem Pana Jezusa dla nas były najbardziej spektakularne charyzmaty Ducha Świętego ${ }^{26}$. Wówczas istnieje niebezpieczeństwo, że nie odkryje się obiektywnego, chrystologicznego kształtu, który ma przybrać życie chrześcijanina.

W homilii należy unikać obydwu tych uproszczeń łącząc ze sobą kształt Chrystusa objawiony w słowie Bożym i działanie Ducha wyrażone w liturgii i chrześcijańskim życiu. W ten sposób prowadzić będziemy do obiektywnego, realnego, doświadczalnego poznania Boga. Należy tu wskazać na jeszcze jeden bardzo ważny element poznania Boga w Duchu Świętym.

24 Por. B. Migut, Teologia liturgiczna szkoły rzymskiej, dz. cyt., s. 104. W celebracji liturgicznej Duch Święty jawi się jako więź pomiędzy przedmiotem wiary a życiem. Por. A. M. Triacca, L' "Hodie” liturgico tra tempo ed eternità, dz. cyt., s. 372.

25 Por. S. Głaz, Analiza doświadczenia mistycznego, w: Doświadczam i wierze, red. S. C. Napiórkowski, K. Kowalik, Lublin 1999, s. 44.

26 Por. List biskupów polskich do kapłanów na Wielki Czwartek 2018 r., Siedem darów z Wieczernika, https://episkopat.pl/siedem-darow-wieczernika-list-biskupow-polskich-do-kaplanow-na-wielki-czwartek-2018-r/ (15.06.2019). 
Jest to poznanie personalne, w którym dzięki działaniu Ducha Bóg staje się moim Abba, a Syn moim Panem. Jest to poznanie osobowe, takie, w którym osoba człowieka wierzącego budzi się w kontakcie ze zwracającym się do niego Bogiem. Poznanie to jest równocześnie zjednoczeniem, upodobaniem i upodobnieniem do Boga. Idąc za Louis Bouyer można tu mówić o poznaniu bezpośrednim rodzącym się z poznania Boga przez Jego obecność i działanie w nas. Jest to poznanie, które Bouyer nazywa „poznaniem żywym”27.

Wspomnieliśmy już wcześniej, że w Eucharystii mamy do czynienia z obiektywną obecnością i działaniem Ducha, co umożliwia wiernym wejście w obiektywne, choć zarazem osobiste doświadczenie Ducha Świętego. Nie podejmujemy się w tym miejscu definiowania terminu „doświadczenie” Boga. Jest to bowiem problem bardzo złożony i wymaga wnikliwej analizy. Wspomnijmy tylko, że doświadczenie, o którym mówimy rożni się od tego, co psychologia nazywa przeżyciem i polega głównie na doświadczeniu Bożej samo komunikacji ${ }^{28}$. Akcent położony jest tu raczej działaniu Ducha Świętego, który jako wolny podmiot udziela się człowiekowi tak, jak chce i kiedy chce (por. J 3,8; Dz 1,14). Działania Ducha nie można „wymusić” przez jakieś „pobożne sztuczki” czy „liturgiczne zabiegi". Duch Święty nie jest bożkiem, którego możemy mieć na "swoje usługi” i według własnego uznania. Duch jest wolny w swoim działaniu i na to wolne działanie możemy się jedynie otworzyć poprzez wiarę, pragnienie i modlitwę. Warto jeszcze raz przypomnieć w tym kontekście: działanie Ducha Świętego w liturgii ma charakter obiektywny, stąd też komunikuje wiernym zbawienie w sposób obiektywny, lecz tak jak On chce.

Celem przepowiadania homilijnego jest zatem wprowadzenie w liturgiczne dzianie się zbawienia i w relację z Osobą Ducha Świętego, który to zbawienie uobecnia. Homilista ma wprowadzać wiernych w liturgiczne

27 Por. L. Bouyer, Wprowadzenie do życia duchowego. Zarys teologii ascetycznej i mistycznej, Warszawa 2014, s. 325-328. 361.

28 Mówiąc o „doświadczeniu religijnym” należałoby je rozumieć w uproszczeniu jako wyższy stopień „postrzegania, jako percepcyjny efekt immanentnego doświadczenia transcendentnego Absolutu". S. Głaz, Analiza doświadczenia mistycznego, dz. cyt., s. 44. Por. M. Kiermacz, Koncepcja doświadczenia w pismach G. O'Collinsa, w: Doświadczam i wierzę, dz. cyt., s. 64. 
„dzianie się” zbawienia. Warto dodać w tym miejscu - co podkreśla wielu współczesnych teologów - że doświadczenie jest jedynym miejscem spotkania osoby ludzkiej ze zbawczym działaniem Boga ${ }^{29}$. Henry Newman ujął ten fakt w sposób następujący: „O Tym, o którym wnioskujemy, choć Go nigdy nie widzieliśmy, możemy mówić jedynie w kategoriach doświadczenia" ${ }^{30}$.

Ważną funkcją homilii jest w tym kontekście pomóc wiernym w nawiązaniu wielopłaszczyznowych relacji z Osobą Ducha Świętego. Nie jest On przecież jakąś bezosobową mocą przekazaną nam przez Ojca. Pamiętajmy przy tym, że do wejścia w relację z Duchem Świętym potrzebna jest odpowiednia „dyspozycja serca” (KKK 1101). Uczestników zgromadzenia liturgicznego trzeba przygotować na spotkanie z Bogiem tak, aby byli „ludem dobrze usposobionym” (KKK 1098). Katechizm przypomina, że jest to zwłaszcza dzieło ,pełniących funkcje wynikające ze święceń (ministri)" (KKK 1098).

Na czym polega owa dyspozycja serca konieczna do wejścia w doświadczenie Ducha? Wskazał na to sam Jezus gdy w czasie święta namiotów zawołał donośnym głosem: „Jeśli ktoś jest spragniony, a wierzy we Mnie - niech przyjdzie do Mnie i pije! Jak rzekło Pismo: Strumienie wody żywej popłyną z Jego wnętrza. A powiedział to o Duchu, którego mieli otrzymać wierzacy w Niego" (J 7, 37-39). Mamy tu zatem dwie jasne dyspozycje: wiara i pragnienie. Osobistego przyjścia Ducha Świętego przyjścia nie można wymusić. Można się jedynie na nie przygotować poprzez modlitwę pełna wiary i pragnienia. W Katechizmie Kościoła katolickiego takie „wejście” w liturgię eucharystyczną przyrównane jest także do „wejścia” w kontemplację i określone w następujący sposób: „«Skupienie» serca; poddanie całej naszej istoty tchnieniu Ducha Świętego; zamieszkanie w domu Pańskim, jakim jesteśmy; pobudzenie wiary, by wejść w obecność Tego, który nas oczekuje; [...] zwrócenie serca do kochającego nas Pana, aby oddać się Mu jako ofiara, która zostanie oczyszczona i przekształcona" (KKK 2711).

${ }^{29}$ M. Kiermacz, Koncepcja doświadczenia w pismach G. O'Collinsa, dz. cyt., s. 64.

30 H. Newman, The Theological Papers of John Henry Newman on Faith and Certainty, ed. H. M. de Achaval, J. D. Holmes, Oxford 1976, s. 102. 
Wiara, pragnienie, modlitewne oczekiwanie, skupienie, osobista dyspozycyjność to są zatem podstawowe dyspozycje konieczne do wejścia w doświadczenie Ducha Świętego w liturgii. Dyspozycje te należy u wiernych ciągle pobudzać, stymulować ${ }^{31}$. Innymi słowy: homilista w swoim przepowiadaniu ma dążyć do tego, aby uczestnicy zgromadzeni liturgicznego byli świadomi Ducha, uważni na Ducha i otwarci na Niego. Reszta dokonuje się jakby naturalnie (lub lepiej: jakby naturalnie nadnaturalnie), to znaczy w osobowej relacji Ducha Świętego z konkretnym wierzącym.

Kolejną funkcją homilii w kontekście żywego poznania Ducha Świętego jest prowadzenie wierzących do wykorzystania darów Ducha Świętego w życiu społecznym. Wierzący ma doświadczenie Ducha Świętego, jeśli wykorzystuje Jego moc do naśladowania Chrystusa - wówczas poznaje Ducha w Jego działaniu. W przepowiadaniu należy zatem dodać wiernym odwagi i wiary, aby podjęli współpracę z Duchem Świętym, aby dali $\mathrm{Mu}$ „się porwać” w konkrecie swej egzystencji. Uczestnicy zgromadzenia liturgicznego powinni współdziałać z Duchem Świętym w uśmiercaniu w sobie skłonności „starego człowieka”. (por. 1 Kor 15, 31) tak, aby dokonywała się w nich zasada stopniowego, duchowego wzrostu.

\section{Zakończenie}

Homilia, jako część celebracji liturgicznej może się skutecznie przyczyniać do tego, że Eucharystia stanie się każdorazowo dla uczestników zgromadzenia liturgicznego doświadczeniem życia w Duchu Świętym. Owo doświadczenie jest głębszym przeżywaniem sakramentu chrztu i ukierunkowane jest na Chrystusa tak, aby zostać do Niego coraz pełniej upodobnionym. Proces tego upodobnienia dokonuje się najpierw w celebracji liturgicznej, w której mamy do czynienia z obiektywną obecnością

${ }^{31}$ Według Triacca, aby celebracja liturgiczna stawała się coraz pełniej miejscem stałej formacji wiary w homilii należy kształtować także i inne „dyspozycje pneumatologiczne" uczestników zgromadzenia liturgicznego, którymi są: uległość natchnieniom Ducha Świętego, chęć i zdolność nauczenia się; oddanie się osobie Ducha Świętego, aby się nami posługiwał, poszerzanie serca. Por. A. M. Triacca, Omelia e Spirito Santo, dz. cyt., s. 149-150. 
i działaniem Ducha. W homilii należy również zaznaczać, że owo „życie w Duchu" ma być kontynuowane w codzienności - po zakończonej Eucharystii. Egzystencjalne doświadczenie Ducha Świętego nosi oczywiście znamię subiektywności - nie jest tak obiektywne jak w liturgii. Jest to jednak rodzaj doświadczenia realnego polegającego na „zjednoczeniu mistycznym” (KKK 2014). Chodzi tu o mistykę rozumianą jako „uczestnictwo w misterium Chrystusa przez sakramenty święte" (KKK 2014) oraz jako wewnętrzne zjednoczenie się z Trójjedynym Bogiem przez poddanie się chrystokształtującemu działaniu Ducha Świętego według słów św. Pawła: „Teraz już nie ja żyję, lecz żyje we Mnie Chrystus” (Ga 2, 20). Przypomnijmy, że gdy Konstytucja o liturgii świętej mówi o homilii wówczas akcentuje dynamiczną obecność misterium Chrystusa (tożsamego z historią zbawienia) w obrzędach liturgicznych oraz w życiu wierzących (KL 35, 2). W takim ujęciu misterium Chrystusa ujmujemy pnuematologię w powiązaniu zarówno z chrystologią, jak i z antropologią. Wówczas Duch Święty jawi się wiernym nie tyle jako Ten, który prowokuje to, co psychologia nazywa „przeżyciem”, lecz jako Ten, który sprawia, że misterium Chrystusa staje się życiem wiernych w liturgii, jak i w codzienności. W tym sensie Duch prowadzi do osobistego przeżycia Ewangelii. Tak też należy postrzegać podstawowy cel każdej homilii. 


\section{Summary}

\section{Działanie Ducha Świętego w Eucharystii a przepowiadanie homilijne}

Liturgia dokonywana jest w Duchu Świętym we wszystkich swoich wymiarach. Każda homilia winna zatem odwoływać się do działania Ducha Świętego, który umożliwia wszelkie działanie liturgiczne. Celem artykułu była odpowiedźna pytania: Jakie jest podstawowe działanie Ducha Świętego w liturgii eucharystycznej? Jaka powinna być treść homilii, aby oddać specyfikę tego działania? Jak wprowadzać wiernych w liturgiczne misterium Ducha Świętego? Odpowiedź ta przedstawiona została w dwóch aspektach. Najpierw wskazano na chrystologiczne ukierunkowanie homilii pneumahagijnej. Następnie zaś przedstawiono sposoby wprowadzenia w doświadczenie Ducha Świętego w liturgii i poza nią.

Słowa klucze: Duch Święty, misterium Chrystusa, Eucharystia, homilia, życie Kościoła, doświadczenie religijne

\section{The Work of the Holy Spirit in the Eucharist and Preaching Homilies}

The liturgy is carried out by the Holy Spirit in all its dimensions. Every homily, therefore, should refer to the work of the Holy Spirit. The goal of the article is to answer the following questions: how does the Holy Spirit basically work in the Eucharistic liturgy? What should be the contents of a homily that reflect on the specificity of his activity? How do we introduce believers to the liturgical mystery of the Holy Spirit? The answers were given within two aspects. First, the Christological orientation of a pneumahagonic homily is pointed out. Next, we present the ways to introduce experiencing the Holy Spirit as part of the liturgical celebration.

Keywords: Holy Spirit, mystery of Christ, Eucharist, homily, Church life, religious experience

\section{Bibliografia}

Bouyer L., Wprowadzenie do życia duchowego. Zarys teologii ascetycznej i mistycznej, Warszawa 2014.

Chrostowski W., Biblijna nauka o Duchu Świętym, w: Jesteśmy napełnieni Duchem Świętym: zeszyt liturgiczny, red. J. Bartoszek, R. Chromy, K. Piechaczek, Katowice 2017, s. 45-58 (Program duszpasterski Kościoła w Polsce na Rok 2017-2018, 4).

Czerwik S., Obecność i działanie Ducha Świętego we wspólnocie świeckich i duchownych sprawujacych liturgię, „Przegląd Pastoralno-Homiletyczny” 2 (1998) nr 2, s. 60-86. 
Dyk S., Duch Święty jako podmiot i treść przepowiadania homilijnego, „Studia Pastoralne" 4 (2008) nr 4, s. 148-170.

Głaz S., Analiza doświadczenia mistycznego, w: Doświadczam i wierzę, red. S. C. Napiórkowski, K. Kowalik, Lublin 1999, s. 43-55.

Greshake G., Być kapłanem dzisiaj, Poznań 2005.

Jan Paweł II, Encyklika „Dominum et Vivificantem” o Duchu Świętym w życiu Kościoła i świata, w: Encykliki Ojca Świętego Jana Pawła II, Kraków 1996, s. 189-256.

Jan Paweł II, List apostolski „Tertio Millennio adveniente” do biskupów, duchowieństwa i wiernych w zwiazku z przygotowaniem Jubileuszu Roku 2000, Poznań 1995.

Katechizm Kościoła katolickiego, Poznań 2002.

Kiermacz M., Koncepcja doświadczenia w pismach G. O'Collinsa, w: Doświadczam i wierzę, red. S. C. Napiórkowski, K. Kowalik, Lublin 1999, s. 57-76.

Kongregacja Kultu Bożego i Dyscypliny Sakramentów, Dyrektorium homiletyczne, tłum. P. Borkowski, Poznań 2015.

List biskupów polskich do kapłanów na Wielki Czwartek 2018 r., Siedem darów $z$ Wieczernika, https://episkopat.pl/siedem-darow-wieczernika-list-biskupow-polskich-do-kaplanow-na-wielki-czwartek-2018-r/ (15.06.2019).

Marsili S., La liturgia, momento stolico della salvezza, w: La liturgia, momento storico della salvezza, a cura di S. Marsili, Torino 1974, s. 33-156 (Anàmnesis, 1).

Marsili S., Mistero di Cristo e liturgia nello Spirito, Città del Vaticano 1986, s. 174.

Migut B., Teologia liturgiczna szkoły rzymskiej, Lublin 2007.

Mühlen H., Die Wirksamkeit des Heilligen Geistes als Ermöglichung jeglichen liturgischen Tuns. Zum Verständnis der Aussagen der "Constitutio de sacra liturgia” über die Präsenz Christi, „Liturgie in der Gemeinde” 2 (1995), s. 40-61.

Newman H., The Theological Papers of John Henry Newman on Faith and Certainty, ed. H. M. de Achaval, J. D. Holmes, Oxford 1976, s. 102.

Ratzinger J./Benedykt XVI, BógJezusa Chrystusa. Medytacje o Bogu Trójjedynym, Kraków 2006.

Sobór Watykański II, Konstytucja i liturgii świętej „Sacrosanctum concilium”, w: Konstytucje, dekrety, deklaracje, Poznań 2002, s. 40-70.

Sobór Watykański II, Konstytucja dogmatyczna o Kościele „Lumen gentium”, w: Konstytucje. Dekrety. Deklaracje, Poznań 2002, s. 104-166.

Sobór Watykański II, Konstytucja duszpasterska o Kościele w świecie wspótczesnym „Gaudium et spes”, w: Konstytucje. Dekrety. Deklaracje, Poznań 2002, s. 538-621.

Sodi M., Teologia liturgiczna sztuka syntezy teologicznej, w: Teologia liturgiczna. W poszukiwaniu syntezy w teologii, red. B. Migut, Lublin 2013, s. 103-138.

Świerzawski W, Kaznodzieja jako mistagog, w: Stuga Słowa, red. W. Przyczyna, Kraków1997, s. 109-118.

Świerzawski W., Duch Święty wobec misterium Chrystusa w sprawowaniu liturgii, w: Fundamentalne rzeczywistości liturgii, red. W. Świerzawski, Sandomierz 2012, s. $135-152$.

Triacca A. M., L ' „Hodie” liturgico tra tempo ed eternità: contributo per una visuale cristiana del tempo, „Ephemerides Liturgicae” 116 (2002), s. 367-380. 
Triacca A. M., La celebrazione liturgica, epifania dello Spirito Santo, „Liturgia” 33 (1999), s. 24-46.

Triacca A. M., Omelia e Spirito Santo: sua presenza ed azione e come parlarne, „Liturgia” 32 (1998), s. 145-158.

Triacca A. M., Spiritualità, w: Dizionario di omiletica, a cura di M. Sodi, A. M. Triacca, Torino-Bergamo 1998, s. 1509n. 